\title{
Hubungan Konsep Diri Akademik dengan Motivasi Berprestasi pada Remaja Awal yang Tinggal di Panti Asuhan di Denpasar
}

\author{
Komang Diah Laxmy Prabadewi dan Putu Nugrahaeni Widiasavitri \\ Program StudiPsikologi, Fakultas Kedokteran, UniversitasUdayana \\ diahlaxmyp@gmail.com
}

\begin{abstract}
Abstrak
Remaja awal adalah masa pembentukan konsep diri. Konsep diri merupakan sekumpulan keyakinan dan perasaan yang dimiliki individu tentang mereka sendiri, meliputi karakteristik fisik, sosial, emosional, aspirasi dan prestasi (Hurlock,1999). Terkait dengan kebutuhan akan prestasi, remaja perlu mengembangkan konsep diri khususnya konsep diri akademik sebagai bekal dalam menghadapi persaingan di dunia kerja kelak. Konsep diri bukan merupakan faktor bawaan sejak lahir, melainkan faktor yang dipelajari dan dibentuk berdasarkan pengalaman individu dalam berhubungan dengan orang lain. Begitu pula dengan konsep diri akademik. Ketika seseorang tinggal pada situasi yang berbeda pada umumnya seperti di panti asuhan, maka hal tersebut dapat mempengaruhi remaja awal dalam membentuk konsep dirinya yang pada akhirnya dapat mempengaruhi keinginan mereka untuk berprestasi. Berdasarkan hal tersebut, maka peneliti ingin melihat apakah ada hubungan antara konsep diri akademik dengan motivasi berprestasi pada remaja awal yang tinggal di panti asuhan.
\end{abstract}

Penelitian ini menggunakan metode penelitian kuantitatif dengan metode analisis korelasi product moment yang melibatkan 120 remaja awal panti asuhan sebagai subjek yang diperoleh dengan menggunakan teknik pengambilan sampel simple random sampling.

Hasil yang diperoleh adalah ada hubungan yang positif dan signifikan antara konsep diri akademik dengan motivasi berprestasi pada remaja awal yang tinggal di panti asuhan di Denpasar, yang ditunjukkan dengan koefisien korelasi (r) antara variabel konsep diri dan motivasi berprestasi adalah 0,588 dengan nilai $p 0.000(p<0,05)$ yang berarti bahwa variabel konsep diri akademik dan variabel motivasi berprestasi saling berkorelasi secara signifikan dan positif dan berada pada intensitas sedang.

Kata kunci : konsep diri, konsep diri akademik, motivasi berprestasi, panti asuhan, remaja awal

\begin{abstract}
Early adolescence is a period for self-concept formation. The self concept is a set of beliefs and feelings of the individual about their own, including physical characteristics, social, emotional, aspiration and achievement (Hurlock, 1999). Concerned with the need of achievement, adolescents need to develop their self-concept specially their academic self-concept as a particular provision in order to face a competition in the work world later. The self concept is not an innate factor, but it is learned and shaped by individual experience in dealing with others. That is equal with the academic self-concept. When a person living in a different situation with the general one, such as live in an orphanage, it can affect early adolescents in shaping their self-concept, at last it can affect their desire to achieve their achievement. According to these conditions, the researchers wanted to see whether there are relationships between academic self-concept and achievement motivation in early adolescents who lives in an orphanage.

This study uses quantitative research methods which is correlation analysis method using product moment that involving 120 early adolescents orphanages as subjects that obtained by using sample taking technique simple random sampling .

The result found in this research, there is a positive and significant relationship between academic self-concept and achievement motivation in early adolescents who lives in orphanages in Denpasar, which is indicated by the correlation coefficient ( $\mathrm{r}$ ) between the variables of self-concept and achievement motivation is 0.588 with $\mathrm{p}$ value $0.000(\mathrm{p}<0.05)$, which means that the variable of academic self-concept and achievement motivation variables correlated significantly and positively and both of those are at moderate intensity
\end{abstract}

Keywords: self concept, academic self-concept, achievement motivation, orphanages, early adolescents 


\section{K. D. L. PRABADEWI DAN P. N. WIDIASAVITRI}

\section{LATAR BELAKANG}

Masa remaja adalah masa yang memiliki arti yang penting. Dikatakan demikian karena pada masa ini, remaja akan mengalami masa transisi dari kanak-kanak menuju dewasa yang mencakup perubahan fisik, kognitif, dan sosioemosional (Santrock, 2007). Monks, dkk (2006) mengatakan remaja adalah individu berusia antara 12-21 tahun yang sedang mengalami masa peralihan dari masa kanakkanak ke masa remaja, dengan pembagian usia 12-15 tahun adalah masa remaja awal, usia 15-18 tahun adalah masa remaja tengah atau madya, dan usia 18-21 tahun adalah masa remaja akhir. Sarwono (2012) menjelaskan, pada masa remaja awal, individu akan mengalami fase peralihan dan masih mengalami kebingungan pada perubahan-perubahan secara fisik yang terjadi pada tubuhnya sendiri, belum mampu mengontrol emosinya sendiri, tidak stabil, tidak puas, rendah diri, dan cepat merasa kecewa. Jahja (2011) menambahkan, pada masa ini peningkatan emosional terjadi sangat cepat, sehingga masa remaja awal dikenal sebagai masa penuh badai dan tekanan. Disamping itu, remaja pada fase ini banyak terjadi tuntutan dan tekanan yang ditunjukkan pada remaja, misalnya mereka diharapkan untuk tidak lagi bertingkah seperti anak-anak, lebih mandiri dan bertanggung jawab. Pada masa remaja madya, akan muncul kemantapan yang menjawab keragu-raguan pada masa remaja awal, dan mulai dapat memunculkan rasa percaya diri serta individu sudah mampu menemukan diri sendiri atau jati dirinya. Sedangkan pada fase remaja akhir, individu sudah mengenal dirinya, mulai memahami arah hidupnya dan menyadari tujuan hidupnya. Erikson (dalam Gross, 2013) mengatakan pada masa remaja, individu kerap kali merasakan kebingungan terhadap dirinya sendiri dan akan muncul pertanyaan seputar "siapakah aku?", dan "kemana aku harus melangkah?" yang merupakan pertanyaan mendasar tentang pemahaman diri remaja, dan bila tidak dapat terjawab dengan segera, akan mempengaruhi proses pembentukan indentitas diri remaja.

Berdasarkan hal tersebut, para ahli psikologi perkembangan menyebut masa remaja sebagai masa paling krisis selama rentang kehidupan. Krisis yang dimaksud adalah masalah yang berkaitan dengan tugas perkembangan yang harus dilalui oleh setiap individu, khususnya pada fase remaja awal, karena pada fase ini adalah masa peralihan dari kanakkanak menuju remaja yang berlangsung cepat dan akan menimbulkan kebingungan serta permasalahan yang kompleks atas perubahan-perubahan yang terjadi, baik secara fisik maupun psikologis. Perubahan-perubahan fisik maupun psikologis tersebut dapat mempengaruhi proses pembentukan identitas diri remaja (Jahja, 2011).

Dariyo (2004) mengatakan, salah satu karakteristik individu yang memiliki identitas diri yang baik adalah dengan konsep diri yang baik pula. Hurlock (1999) mengartikan, konsep diri sebagai gambaran diri tentang aspek fisiologis maupun psikologis yang berpengaruh pada perilaku individu dalam penyesuaian diri dengan orang lain. Sejauh mana individu menyadari dan menerima segala kelebihan dan kekurangan yang ada pada dirinya, maka akan berpengaruh terhadap pembentukan konsep dirinya. Konsep diri juga merujuk pada gambaran tentang peran yang kita lakukan yang terbentuk sebagai hasil dari makin banyak atau seringnya kita berinteraksi dengan orang lain (Agustiani, 2006). Rini (dalam Sarwono, 2012) mengatakan bahwa salah satu faktor yang dapat mempengaruhi konsep diri remaja adalah peran orang tua. Berdasarkan penelitian yang dilakukan oleh Coopersmith (dalam Jahja, 2011) tentang peranan kondisi keluarga dibandingkan dengan kondisi sosial terhadap pembentukan konsep diri, membuktikan bahwa kondisi keluarga yang buruk dapat membentuk konsep diri yang negatif pada anak, dan konsep diri yang positif akan muncul pada keluarga yang memiliki integritas dan tenggang rasa yang tinggi antar anggota keluarga. Mengacu pada penelitian yang dilakukan oleh Coopersmith (dalam Jahja, 2011), untuk membangun konsep diri yang baik, anak memerlukan perhatian dan bimbingan dari orangtuanya, karena di dalam keluarga, orangtua memegang peranan yang penting dalam membentuk keluarga yang penuh kehangatan, memiliki ikatan emosional yang kuat dan mampu mengembangkan potensi serta individualitas anggotanya. Akan tetapi pada kenyataannya, tidak semua manusia dalam perjalanan hidupnya beruntung dapat memiliki keluarga yang utuh dan ideal. Banyak anak yang mengalami kenyataan pahit dalam hidupnya, lahir tanpa orang tua karena kematian atau perceraian, kemiskinan, keluarga tidak harmonis, dan lain sebagainya yang dapat menyebabkan hilangnya fungsi keluarga, sehingga anak harus rela terlepas dari kasih sayang kedua orang tuanya atau kadang harus menjalani kerasnya kehidupan sendiri tanpa adanya peran keluarga.

Berdasarkan Undang-Undang Republik Indonesia No.4 Tahun 1979 pasal 2 ayat 1, menjelaskan bahwa setiap anak berhak untuk mendapat kesejahteraan, perawatan, asuhan, dan bimbingan berdasarkan kasih sayang baik dalam keluarganya maupun di dalam asuhan khusus untuk tumbuh dan berkembang wajar (Dewi, 2011). Sejalan dengan Peraturan Perundang-undangan tersebut, Pemerintah menyediakan suatu wadah yang sekiranya dapat membantu memenuhi kebutuhan jasmani, rohani dan sosial dari anakanak yang hidup tanpa didampingi oleh orang tua dan keluarganya, agar mereka dapat tumbuh dan berkembang layaknya anak yang diasuh dalam keluarga yang sebenarnya, yaitu panti asuhan.

Panti asuhan adalah salah satu lembaga perlindungan anak yang berfungsi untuk memberikan perlindungan terhadap anak-anak yang tidak mendapatkan haknya (Anonim, 2012). Panti asuhan juga terbuka untuk anak-anak yang masih memiliki orang tua lengkap yang dalam status ekonomi 
keluarga yang rendah, namun tetap menginginkan pendidikan yang terjamin untuk anaknya.

Setiap panti asuhan tentunya memiliki pengasuh sebagai pengganti orang tua untuk para penghuni panti asuhan. Mussen (dalam Assharra, 2004) mengatakan bahwa para penghuni panti asuhan dapat mengembangkan dirinya secara maksimal dengan adanya bimbingan dan perhatian dari pengasuh. Akan tetapi, kenyataan yang ada di panti asuhan pada saat ini sering tidak sejalan dengan kondisi yang seharusnya terjadi. Seperti penelitian yang dilakukan oleh Splitz (dalam Prabawa, 2009) yang mengatakan bahwa para penghuni panti asuhan, khususnya di negara-negara berkembang mengalami apa yang disebut dengan hospitalism yaitu tidak terpenuhinya kebutuhan akan kasih sayang atau afeksi sehingga terasing secara emosional. Banyak faktor yang menyebabkan keterasingan emosional tersebut, misalnya karena kurangnya perhatian dari pengasuh akibat keterbatasan tenaga pengasuh, kurangnya fasilitas fisik, terlalu ketatnya disiplin dan aturan yang dijalankan yang memungkinkan anak tersebut cenderung menampakkan sikap pendiam, pasif, kurang responsif terhadap orang lain dan merasa rendah diri, sehingga cenderung menarik diri dan lebih bersikap defensif dalam pergaulan (Assahrra, 2004). Selain itu, para penghuni panti asuhan juga kerap mendapatkan pandangan yang negatif dari lingkungan, seperti dicap sebagai "anak panti”, dikatakan miskin karena ketidakmampuan dalam mengikuti tren masa kini sehingga mendapat penolakan dari teman-teman disekolahnya, dan adanya pengasuh panti asuhan yang mencemooh anak asuhnya karena tidak mampu mengerjakan tugas sekolahnya dengan baik. Permasalahan-permasalahan tersebut dapat mempengaruhi pembentukan konsep diri para penghuni panti asuhan.

Saat ini permasalahan utama yang banyak dihadapi panti asuhan di Indonesia adalah keterbatasan dana (Soepeno, 2011). Hal tersebut tentunya dapat berdampak pada para penghuni panti asuhan. Dampak tersebut dapat terlihat dari wawancara awal yang peneliti lakukan dengan beberapa remaja awal yang tinggal di panti asuhan di Denpasar, khususnya remaja awal. Hasil yang diperoleh adalah beberapa remaja awal mengatakan mereka cukup kekurangan akan ketersediaan fasilitas fisik seperti buku tulis dan buku pelajaran. Mereka mengatakan harus menabung terlebih dahulu jika ingin mendapatkan peralatan belajar tambahan, tetapi mereka mengaku sangat susah untuk dapat menabung karena uang jajan yang diberikan pengasuh tidak banyak. Mereka mengatakan hanya bergantung pada donatur yang berkunjung ke panti saja. Beberapa dari mereka juga merasakan konflik psikologis seperti menganggap diri mereka tidak dapat dibanggakan karena hampir tidak pernah mendapat peringkat kelas, bahkan salah satu remaja mengaku bahwa pernah tidak naik kelas. Hal tersebut menjadikan mereka tidak percaya diri dengan kondisi mereka.
Salah satu remaja lainnya mengatakan masih ada beberapa teman mereka yang membedakan status dan memilih tidak ingin berteman dengan mereka karena status mereka sebagai penghuni panti asuhan. Hal itu membuat mereka sedikit membatasi diri dalam pergaulan. Berbagai konflik yang mereka alami, diakui cukup menghambat mereka dalam mengembangkan potensi diri, dan mereka menganggap kebutuhan akan prestasi bukanlah merupakan suatu keharusan.

Pada umumnya, masa remaja adalah masa untuk berprestasi, dimana para remaja akan menyadari bahwa pada saat ini mereka dituntut untuk menghadapi kehidupan yang sebenarnya yang sarat akan persaingan. Menurut Santrok (2007), keberhasilan atau kegagalan pada saat remaja dapat menjadi prediktor bagi keberhasilan yang akan diperoleh remaja pada saat dewasa. Prestasi bagi remaja sangat penting karena apabila remaja memiliki prestasi tentu akan memperoleh status pekerjaan yang lebih besar di masa yang akan datang. Maka dari itu dapat dikatakan bahwa, prestasi merupakan sarana untuk melatih kesempatan yang pada akhirnya makin terbuka kesempatan dalam dunia kerja. Pada tahapan inilah remaja diharapkan dapat mengembangkan konsep diri khususnya konsep diri akademik yang positif sebagai salah satu acuan untuk berprestasi. Untuk itu, dalam usaha mencapai keberhasilan dan prestasi tersebut, diperlukan adanya motivasi. Menurut Mc Clelland (dalam Djamarah, 2011) motivasi berprestasi merupakan daya penggerak yang memotivasi semangat bekerja seseorang, yang mendorong seseorang untuk mengembangkan kreativitas dan menggerakkan semua kemampuan serta energi yang dimilikinya demi mencapai prestasi kerja yang maksimal.

Begitu pula dengan remaja awal yang tinggal di panti asuhan, yang sedang berada pada masa rawan dan tidak stabil, sangat diperlukan adanya kondisi lingkungan yang kondusif untuk membentuk suatu konsep diri yang positif, mengingat konsep diri didapat melalui proses belajar.

Fernald dan Fernald (1999) mengatakan dalam memunculkan motivasi seseorang untuk berprestasi dipengaruhi oleh banyak hal, salah satunya adalah konsep diri. Konsep diri sebagai gagasan tentang diri sendiri yang berisi cara pandang individu terhadap dirinya sebagai pribadi. Begitu pula dengan konsep diri akademik. Secara umum, tidak terdapat pengertian spesifik terkait konsep diri akademik, namun Strein (dalam byrne, 1996) mengemukakan bahwa konsep diri akademik harus memiliki dua karakteristik penting yaitu adanya unsur deskriptif dan evaluatif, serta menekankan pada kompetensi skolastik. Apabila remaja awal panti asuhan tersebut memandang positif terhadap kemampuan akademik yang dimilikinya, maka remaja awal tersebut akan merasa yakin bahwa dirinya bisa dan mampu sehingga memungkinkan dirinya untuk termotivasi dalam meraih prestasi. Sebaliknya, apabila remaja awal panti asuhan memandang negatif kemampuan akademik yang dimilikinya 


\section{K. D. L. PRABADEWI DAN P. N. WIDIASAVITRI}

maka remaja awal tersebut akan merasa bahwa dirinya tidak mampu untuk mencapai suatu prestasi sehingga dalam dirinya kurang memiliki motivasi untuk meraih prestasi.

Melihat kenyataan bahwa remaja panti asuhan memiliki permasalahan secara psikologis yang berkaitan dengan konsep diri khususnya dalam hal akademik, dan dapat mempengaruhi keinginan mereka untuk berprestasi, membuat peneliti ingin mengetahui apakah ada hubungan konsep diri dengan motivasi berprestasi pada remaja, dengan fokus pada remaja awal yang tinggal di panti asuhan di Denpasar, mengingat usia remaja awal merupakan usia rentan remaja dalam menentukan konsep diri sebagai cerminan diri dimasa depan kelak.

\section{METODE}

\section{Variabel dan definisi operasional}

Identifikasi variabel yang terdapat dalam sebuah penelitian berfungsi untuk menentukan alat pengumpulan data dan teknik analisis yang akan digunakan. Pada penelitian ini, peneliti menetapkan dua jenis variabel yaitu variabel bebas dan variabel tergantung. Variabel bebas dalam penelitian ini adalah konsep diri akademik dan variabel tergantung dalam penelitian ini adalah motivasi berprestasi.

Definisi operasional variabel bebas, konsep diri akademik adalah pandangan dan keyakinan individu mengenai kompetensi dirinya dalam bidang akademik, yang memiliki dua karakteristik penting yaitu adanya unsur deskriptif dan evaluatif, serta menekankan pada kompetensi skolastik yang diperoleh dengan melibatkan pengalaman-pengalaman psikologis yang kemudian dapat menentukan individu dalam bertindak dan berperilaku. Konsep diri akademik diukur dengan menggunakan skala konsep diri yang disusun oleh peneliti melalui aspek-aspek yang melibatkan aspek fisik, psikis, sosial, dan moral dan oleh Berzonky (dalam susilowati, 2011) dengan menekankan pada unsur deskriptif, evaluatif dan skolastik.

Definisi operasional variabel tergantung, motivasi berprestasi adalah dorongan yang penuh energi yang menuntut seseorang untuk menggerakkan semua kemampuannya demi mencapai prestasi yang maksimal dari dirinya. Motivasi berprestasi diukur menggunakan Skala pengukuran motivasi berprestasi. Adapun aspek-aspek dari variabel motivasi berprestasi menurut Mc Clelland (dalam Djamarah, 2011) adalah, resiko dalam pemilihan tugas, memperhatikan umpan balik tentang perbuatannya, ketekunan, tanggung jawab, dan inovatif.

Alat ukur yang digunakan dalam kedua kuesioner pada penelitian ini adalah skala likert. Skala likert adalah skala yang dapat digunakan untuk mengukur sikap, pendapat, dan persepsi seseorang atau sekelompok orang mengenai suatu gejala atau fenomena. Skala likert dalam kuesioner dukungan suami ini terdiri dari 5 kategori jawaban yaitu, Sangat Setuju (SS), Setuju (S), Netral (N), Tidak Setuju (TS), dan Sangat Tidak Setuju (STS).

\section{Responden}

Populasi adalah wilayah generalisasi yang terdiri atas objek atau subjek yang mempunyai kuantitas dan karakteristik tertentu yang ditetapkan oleh peneliti untuk dipelajari dan kemudian ditarik kesimpulannya (Sugiyono, 2008). Peneliti menggunakan remaja awal panti asuhan di Denpasar sebagai populasi dalam penelitian ini. Sampel penelitian ini diambil dari populasi yang memenuhi kriteria inklusi yang telah ditetapkan oleh peneliti. Adapun kriteria inklusi dalam penelitian ini adalah :

\section{Kriteria Inklusi Subjek Penelitian}

a. Remaja awal dengan rentang usia 12-15 tahun.

b. Tercatat sebagai penghuni panti asuhan di Denpasar.

c. Saat ini tercatat sebagai siswa atau siswi dengan pendidikan formal, yaitu pada jenjang Sekolah Dasar (atau sederajat), dan Sekolah Menengah Pertama (atau sederajat).

d. Bersedia untuk menjadi subjek penelitian.

2. Kriteria Eksklusi Subjek Penelitian

a. Remaja awal yang tidak tinggal di panti asuhan di Denpasar.

b. Remaja awal yang tidak bersedia untuk menjadi subjek penelitian.

c. Remaja awal yang tidak bersekolah.

Teknik yang digunakan dalam pengambilan sampel adalah teknik random sampling yaitu pengambilan sampel secara acak dan sederhana. Pengambilan sampel dikhususkan pada remaja awal dengan usia 12-15 tahun yang tersebar di sebelas panti asuhan di Denpasar. Adapun jumlah minimal sampel yang digunakan dalam penelitian ini menggunakan pertimbangan rumus Slovin, karena jumlah populasi yang telah diketahui sebelumnya. Maka diketahui bahwa jumlah minimal sampel adalah 112 orang dan pada penelitian ini menggunakan 120 remaja awal sebagai sampel.

\section{Tempat penelitian}

Penelitian ini dilakukan di sebelas panti asuhan yang tersebar di kota Denpasar, yaitu panti asuhan Darmajati II, panti asuhan KH.Mas Mansyur putra, panti asuhan KH. Mas Mansyur putri, panti asuhan Bala Keselamatan Putra William Booth, panti asuhan Anugerah (Putri) Bala Keselamatan, panti asuhan Tunas Bangsa, panti asuhan Sunya Giri, panti asuhan Tat Twam Asi, panti asuhan Al-Islam Hidayatullah, panti asuhan Elisama, dan panti asuhan Eben Heizer.

Sebelum melakukan penelitian, peneliti melakukan try out dengan menyebar kuesioner kepada sejumlah 36 remaja awal panti asuhan dan dilaksanakan pada tanggal 15 juni 2013. 


\section{Alat ukur}

Variabel bebas pada penelitian ini adalah konsep diri akademik, dan variabel tergantung dalam penelitian ini adalah motivasi berprestasi. Alat ukur yang digunakan dalam penelitian ini adalah dengan menggunakan kuesioner yang telah disusun berdasarkan aspek- aspek konsep diri akademik oleh Berzonky (dalam Kusumawardani, 2011), dan aspekaspek motivasi berprestasi menurut Mc Clelland (dalam Djamarah, 2011). Untuk mengetahui seberapa positif konsep diri akademik dan seberapa tinggi motivasi berprestasi pada remaja awal yang tinggal di panti asuhan di Denpasar, peneliti menggunakan kuesioner konsep diri akademik dan kuesioner motivasi berprestasi yang masing-masing terdiri dari 39 dan 32 aitem pernyataan favorable dan unfavorable. Skala pengukuran yang digunakan pada kuesioner konsep diri akademik ini adalah skala likert dengan pilihan 5 jawaban yaitu, Sangat Setuju (SS), Setuju (S), Netral (N), Tidak setuju (TS), dan Sangat Tidak Setuju (STS).

Kategorisasi skor dilakukan untuk memberikan gambaran umum mengenai konsep diri akademik dan motivasi berprestasi pada remaja awal panti asuhan di Denpasar. Kategorisasi ini dilakukan dengan menggunakan metode distribusi frekuensi dimana nantinya hasil skor kuesioner dari aitem-aitem yang telah valid dan reliabel akan dikelompokkan ke dalam lima kategori. Pada variabel konsep diri akademik, aitem akan dikelompokkan menjadi lima kategori yaitu: sangat negatif, negatif, menengah, positif, dan sangat positif, sedangkan pada variabel motivasi berprestasi, aitem akan dikelompokkan menjadi lima kategori yaitu: sangat rendah, rendah, sedang, tinggi, dan sangat tinggi.

Sebelum alat ukur digunakan dalam melakukan penelitian dilaksanakan uji coba terlebih dahulu terhadap kuesioner. Peneliti menyebar sejumlah 36 kuesioner yang dibagikan kepada 36 remaja awal panti asuhan di Denpasar, termasuk diantaranya remaja awal dengan jenis kelamin lakilaki dan perempuan. Jumlah kuesioner yang kembali adalah sama yaitu sebanyak 36 kuesioner. Hal tersebut karena peneliti berada ditempat pada saat proses pengambilan data berlangsung, dan peneliti menghitung ulang jumlah kuesioner yang kembali agar tetap sama dengan jumlah kuesioner yang keluar. Selanjutnya, melalui uji kesahihan aitem pada skala konsep diri akademik, terdapat 11 aitem gugur dari total 50 aitem pernyataan. Koefisien korelasi bergerak dari 0,302 hingga 0,770. Validitas aitem konsep diri akademik berada di atas nilai 0,3 sehingga seluruh aitem dalam kuesioner dinyatakan valid (Azwar, 2012). Pada skala konsep diri akademik dalam penelitian ini, terdapat 39 jumlah aitem yang sahih. Reliabilitas konsep diri akademik adalah 0,929, sehingga skala ini dikatakan mempunyai daya keterandalan yang tinggi sekali (Guilford, 1956).

Uji coba yang dilakukan pada kuesioner motivasi berprestasi, terdapat 12 aitem yang gugur dari 44 aitem yang diuji dimana diperoleh koefisien korelasi yang bergerak dari 0,309 hingga 0,666. Validitas aitem konsep diri akademik berada di atas nilai 0,3 sehingga seluruh aitem dalam kuesioner dinyatakan valid (Azwar, 2012). Maka, jumlah aitem yang sahih pada skala motivasi berprestasi adalah sebanyak 32 aitem. Reliabilitas skala motivasi berprestasi adalah 0,924 sehingga dikatakan skala ini memiliki daya keterandalan yang tinggi sekali (Guilford, 1956).

\section{Metode pengumpulan data}

Metode pengumpulan data pada penelitian ini adalah dengan menggunakan kuesioner tertutup yang berisi skala pengukuran instrumen penelitian, yaitu skala Likert dengan berisi sejumlah aitem pernyataan favorable dan unfavorable degan lima pilihan jawaban yaitu sangat setuju (SS), setuju (S), Netral (N), tidak setuju (TS), dan sangat tidak setuju (STS). Kuesioner terdiri dari tiga bagian. Bagian pertama adalah berisi identitas responden, bagian kedua adalah kuesioner yang berisi pernyataan yang mengungkap konsep diri akademik dan bagian ketiga berupa kuesioner berisi pernyataan untuk mengungkap motivasi berprestasi.

\section{Teknik Analisis Data}

Analisis data yang digunakan dalam penelitian ini adalah analisis korelasi pearson product moment yang dikemukakan oleh Karl Pearson. Analisis ini digunakan karena merupakan analisis korelasional yang dapat dipakai untuk mengetahui derajat hubungan dan kontribusi variabel bebas dengan variabel tergantung (Riduwan \& Sunarto, 2009). Sebelum menggunakan teknik analisis korelasi pearson product moment, maka data terlebih dahulu melewati uji asumsi data penelitian dengan uji normalitas dan linearitas. Uji normalitas bertujuan untuk mengetahui kenormalan distribusi sebaran skor variabel bebas yaitu konsep diri akademik dan variabel tergantung yaitu motivasi berprestasi. Uji normalitas dapat dilakukan dengan kolmogorof Smirnov. Suatu sebaran dikatakan normal apabila hasil $\mathrm{p}>0.05$ dan sebaliknya suatu sebaran dikatakan tidak normal apabila hasil $\mathrm{p}<0.05$. Uji normalitas data penelitian ini menggunakan perangkat lunak SPSS 17.0 dalam pengolahan data. Setelah data dikatakan normal, maka tahap selanjutnya adalah melakukan uji linearitas. Uji ini dipergunakan untuk mengetahui apakah dua variabel yang dikenai prosedur analisis statistik korelasional menunjukan hubungan yang linear atau tidak. Untuk mendeteksi data penelitian berhubungan secara linear atau tidak, maka dapat diketahui dengan melihat nilai signifikan linearitas. Jika $\mathrm{p}>0.05$, maka dinyatakan hubungan dua variabel tidak linear. Namun jika nilai $\mathrm{p}<0.05$, maka dinyatakan hubungan dua variabel penelitian adalah linear.

Setelah uji normalitas dan linearitas dilakukan dan mendapat data yang normal dan linear, selanjutnya dilakukan 


\section{K. D. L. PRABADEWI DAN P. N. WIDIASAVITRI}

uji hipotesis dengan menggunakan analisis korelasi product moment. Suatu pengujian hipotesis yang dilakukan untuk menentukan apakah hipotesis tersebut secara statistik dapat diterima atau ditolak.

Hasil menunjukkan terdapat hubungan antar variabel maka dikatakan bahwa terdapat hubungan konsep diri akademik dengan motivasi berprestasi pada remaja awal yang tinggal di panti asuhan di Denpasar. Untuk melihat adanya hubungan dilakukan dengan uji hipotesis dengan melihat nilai p. Apabila $\mathrm{p}<0,05$, artinya hipotesis nol ditolak dan hipotesis alternatif diterima yang menyatakan bahwa ada hubungan positif antara konsep diri akademik dan motivasi berprestasi pada remaja awal yang tinggal di panti asuhan di Denpasar. Sebaliknya, apabila nilai $\mathrm{p}>0,05$ artinya hipotesis nol diterima dan hipotesis alternatif ditolak yang menyatakan bahwa tidak ada hubungan positif dan signifikan antara konsep diri akademik dan motivasi berprestasi pada remaja awal yang tinggal di panti asuhan di Denpasar.

\section{HASIL PENELITIAN}

Penelitian ini merupakan jenis penelitian korelasional yaitu ingin melihat apakah terdapat hubungan antara konsep diri akademik dengan motivasi berprestasi pada remaja awal yang tinggal di panti asuhan di Denpasar. Uji hipotesis yang digunakan dalam penelitian ini adalah dengan korelasi product moment oleh Karl Pearson. Sebelum melakukan analisis menggunakan product moment, terdapat dua syarat yang harus dipenuhi sebelumnya, yaitu dilakukannya uji asumsi berupa uji normalitas dan linearitas. Uji normalitas dan linearitas dilakukan dengan alat bantu perangkat lunak SPSS 17.0.

Tabel 1

Uji Normalitas Sebaran Data Konsep Diri Akademik dan Motivasi Berprestasi

One-Sample Kolmogorov-Smirnov Test

\begin{tabular}{|ll|r|r|}
\hline & & TOTKDA & \multicolumn{1}{|c|}{ TOTMB } \\
\hline Normal Parameters ${ }^{3 . .0}$ & Mean & 120 & 120 \\
& Std. Deviation & 142.96 & 112.21 \\
& Absolute & 14.822 & 13.343 \\
Most Extreme Differences & .074 & .084 \\
& Positive & .046 & .084 \\
& Negative & -.074 & -.054 \\
& Kolmogorov-Smirnov Z & .813 & .918 \\
& Asymp. Sig. (2-tailed) & .523 & .368 \\
\hline $\begin{array}{l}\text { a. Test distribution is Normal. } \\
\text { b. Calculated from data. }\end{array}$ & & \\
\hline
\end{tabular}

Hasil uji normalitas dengan sampel 120 remaja awal menunjukkan bahwa variabel konsep diri akademik dan motivasi berprestasi masing-masing memiliki nilai signifikansi (p) 0,523 dan (p) 0,368 atau memiliki nilai p diatas 0,05 (p > $0,05)$ hal tersebut menunjukkan bahwa data berdistribusi normal.
Tabel 2

Uji Linearitas Variabel Konsep Diri Akademik dan Motivasi Berprestasi

\begin{tabular}{|c|c|c|c|c|}
\hline \multicolumn{5}{|c|}{ ANOVA Table } \\
\hline & & & $\begin{array}{l}\text { Sum of } \\
\text { Squares }\end{array}$ & df \\
\hline \multirow[t]{5}{*}{$\begin{array}{l}\text { TOTMB * } \\
\text { TOTKD }\end{array}$} & $\begin{array}{l}\text { Between } \\
\text { Groups }\end{array}$ & (Combined) & 13579.858 & 52 \\
\hline & & Linearity & 7316.359 & 1 \\
\hline & & $\begin{array}{l}\text { Deviation from } \\
\text { Linearity }\end{array}$ & 6263.499 & 51 \\
\hline & & Within Groups & 7607.933 & 67 \\
\hline & & Total & 21187.792 & 119 \\
\hline
\end{tabular}

ANOVA Table

\begin{tabular}{|c|c|c|c|c|c|}
\hline & & & $\begin{array}{l}\text { Mean } \\
\text { Square }\end{array}$ & $F$ & S. \\
\hline \multirow{4}{*}{$\begin{array}{l}\text { TOTMB * } \\
\text { TOTKDA }\end{array}$} & \multirow{4}{*}{$\begin{array}{l}\text { Between } \\
\text { Groups }\end{array}$} & (Combined) & 261.151 & 2.300 & .001 \\
\hline & & Linearity & 7316.359 & 64.432 & .000 \\
\hline & & $\begin{array}{l}\text { Deviation from } \\
\text { Linearity }\end{array}$ & 122.814 & 1.082 & .378 \\
\hline & & Within Groups & 113.551 & & \\
\hline
\end{tabular}

Hasil pengujian menunjukkan bahwa hubungan kedua variabel adalah linear karena memiliki nilai $\mathrm{p}$ sebesar 0,000 atau memiliki taraf signifikansi untuk linearitas lebih kecil dari 0,05 ( $\mathrm{p}<0,05)$ sehingga dikatakan bahwa hubungan antara skor variabel konsep diri akademik dan motivasi berprestasi telah menunjukkan adanya garis yang sejajar atau lurus. Berdasarkan uji normalitas dan uji linearitas yang telah dilakukan diperoleh hasil bahwa data penelitian bersifat normal dan bersifat linear sehingga analisis dapat dilanjutkan.

Uji hipotesis pada penelitian ini adalah dengan menggunakan analisis korelasi product moment dari Karl Pearson dan dilakukan secara komputasi melalui program SPSS versi 17.0 dengan taraf signifikansi 0,05 artinya bahwa kemungkinan penolakan hipotesis yang benar adalah 5 diantara 100. Dengan kata lain, kepercayaan terhadap kebenaran hipotesis adalah sebesar 95\%. Hasil yang diperoleh akan ditampilkan pada tabel berikut;

Tabel 3

Hasil Uji Korelasi

\begin{tabular}{|c|c|c|}
\hline & & $\begin{array}{c}\text { Total } \\
\text { Konsep Diri Akademik }\end{array}$ \\
\hline Total & Pearson Correlation & $.588 \div$ \\
\hline Motivasi & Sig. (2-tailed) & .000 \\
\hline Berprestasi & $\mathrm{N}$ & 120 \\
\hline
\end{tabular}

Berdasarkan tabel diatas diketahui bahwa diperoleh nilai koefisien korelasi (r) sebesar 0,588. Angka korelasi yang diperoleh sebesar (+) 0,588 menunjukkan adanya hubungan antara variabel konsep diri akademik dan variabel motivasi berprestasi dan berada pada intensitas sedang. Sedangkan tanda positif (+) menunjukkan bahwa semakin positif konsep diri akademik maka akan mengakibatkan semakin tinggi pula motivasi berprestasi. Hal ini memiliki arti bahwa kedua variabel memiliki hubungan atau saling berkorelasi.

Koefisien determinasi (r2) diperoleh dengan mengkuadratkan nilai $\mathrm{r}(0,588)$ sehingga didapatkan hasil $\mathrm{r} 2$ 
sebesar 0,345. Koefisien determinasi menunjukkan besarnya peran atau sumbangan yang dapat diberikan oleh variabel bebas terhadap variabel tergantung. Dalam penelitian ini, sumbangan variabel konsep diri akademik terhadap variabel motivasi berprestasi sebesar $34,5 \%$. Sedangkan sumbangan selain dari variabel konsep diri akademik terhadap variabel motivasi berprestasi adalah sebesar $65,5 \%$, yang diperoleh dari faktor-faktor lainnya.

Peneliti membedakan kategori dari masing-masing variabel dengan menggunakan rumus rentangan berdasarkan standar deviasi dan mean empiris dilihat dari kurva normal (Azwar, 2012). Kategorisasi yang dilakukan oleh peneliti terbagi kedalam 5 kategori, yaitu kategori sangat negatif, negatif, menengah, positif dan sangat positif pada kategori konsep diri akademik dan kategori sangat rendah, rendah, sedang, tinggi, serta sangat tinggi pada kategori motivasi berprestasi.

Pengkategorian skor dukungan konsep diri akademik dan motivasi berprestasi berikut persentasenya akan dicantumkan dalam tabel-tabel dibawah ini;

Tabel 4

Kategorisasi Subjek pada Skala Konsep Diri Akademik

\begin{tabular}{|c|c|c|c|c|}
\hline Variabel & Rentang Nilai & Kategori & Subjek & Persentase \\
\hline Konsep & $\mathrm{X} \leq 78$ & Sangat negatif & 0 orang & $0 \%$ \\
\cline { 2 - 5 } $\begin{array}{c}\text { Diri } \\
\text { Akademik }\end{array}$ & $78 \leq \mathrm{X} \leq 104$ & Negatif & 1 orang & $0,83 \%$ \\
\cline { 2 - 5 } & $104 \leq \mathrm{X} \leq 130$ & Menengah & 22 orang & $18,33 \%$ \\
\cline { 2 - 5 } & $130 \leq \mathrm{X} \leq 156$ & positif & 76 orang & $63,33 \%$ \\
\cline { 2 - 5 } & $156<\mathrm{X}$ & Sangat positif & 21 orang & $17,5 \%$ \\
\hline \multicolumn{3}{|c|}{ Jumlah } & $\begin{array}{c}120 \\
\text { orang }\end{array}$ & $100 \%$ \\
\hline
\end{tabular}

Melalui tabel diatas, dapat dilihat bahwa terdapat 21 orang atau sebesar $17,5 \%$ responden yang masuk ke dalam kategori konsep diri akademik sangat positif, 76 orang atau $63,33 \%$ responden masuk dalam kategori konsep diri akademik positif, 22 orang atau sebesar 18,33\% responden masuk dalam ketegori konsep diri akademik menengah, dan 1 orang atau sebesar $0,83 \%$ responden masuk dalam kategori konsep diri akademik negatif. Sedangkan untuk kategori konsep diri akademik sangat negatif, tidak terdapat responden atau sebesar $0 \%$.

Tabel 5

Kategorisasi Subjek pada Skala Motivasi Berprestasi

\begin{tabular}{|c|c|c|c|c|}
\hline Variabel & Rentang Nilai & Kategori & Subjek & Persentase \\
\hline \multirow{5}{*}{$\begin{array}{l}\text { Motiva } \\
\text { si } \\
\text { Berpres } \\
\text { tasi }\end{array}$} & $\mathrm{X} \leq 64,05$ & Sangat Rendah & 0 orang & $0 \%$ \\
\hline & $64,05 \leq \mathrm{X} \leq 85,35$ & Rendah & 3 orang & $2,5 \%$ \\
\hline & $85,35 \leq \mathrm{X} \leq 106,65$ & Sedang & 36 orang & $30 \%$ \\
\hline & $\begin{array}{c}106,65 \leq \mathrm{X} \leq \\
127,95\end{array}$ & Tinggi & 64 orang & $53,33 \%$ \\
\hline & $127,95<\mathrm{X}$ & Sangat Tinggi & 17 orang & $14,17 \%$ \\
\hline \multicolumn{3}{|c|}{ Jumlah } & 120 orang & $100 \%$ \\
\hline
\end{tabular}

Melalui tabel diatas, dapat dilihat bahwa terdapat 17 orang atau sebesar $14,17 \%$ responden masuk dalam kategori motivasi berprestasi sangat tinggi, 64 orang atau sebesar $53,33 \%$ responden masuk dalam kategori motivasi berprestasi tinggi, 36 orang atau sebesar $30 \%$ responden masuk dalam kategori motivasi berprestasi sedang, dan 3 orang atau sebesar 2,5\% responden masuk dalam kategori rendah. Sedangkan untuk kategori motivasi berprestasi sangat rendah, tidak terdapat responden atau $0 \%$.

\section{PEMBAHASAN DAN KESIMPULAN}

Berdasarkan hasil analisis korelasional dengan menggunakan teknik analisis korelasi product moment didapat hasil bahwa nilai koefisien korelasi (r) antara variabel konsep diri akademik dan motivasi berprestasi adalah sebesar 0,588 dimana nilai $\mathrm{p}$ sebesar 0,000 ( $\mathrm{p}<0,05)$ yang berarti bahwa variabel konsep diri akademik dan variabel motivasi berprestasi saling berkorelasi secara signifikan dan positif. Hubungan yang positif dapat diartikan bahwa, semakin positif konsep diri akademik, maka semakin tinggi motivasi berprestasi yang dimiliki remaja awal panti asuhan di Denpasar, dan sebaliknya, semakin negatif konsep diri akademik, semakin rendah motivasi berprestasi yang dimiliki remaja awal panti asuhan di Denpasar. Dengan demikian dapat disimpulkan bahwa hipotesis alternatif (Ha) yang diajukan dalam penelitian ini dapat diterima, yaitu ada hubungan antara konsep diri akademik dengan motivasi berprestasi pada remaja awal yang tinggal di panti asuhan di Denpasar. Koefisien determinasi (r2) yang diperoleh dari hubungan konsep diri akademik dengan motivasi berprestasi adalah sebesar 0,345. Hal ini menunjukkan bahwa peranan konsep diri akademik terhadap pembentukan motivasi berprestasi adalah sebesar $34,5 \%$.

Franken (dalam Huitt, 2009) juga menyatakan bahwa terdapat penelitian yang menunjukkan bahwa konsep diri merupakan dasar semua perilaku yang bermotivasi. Konsep diri yang memberikan peningkatan diri menuju ideal, dan diri ideal yang menciptakan motivasi dalam perilaku. Konsep diri adalah pandangan dan keyakinan individu mengenai dirinya sendiri yang mencakup fisik, psikis, sosial dan moral.

Menurut Fuhrman (dalam kusumawardani, 2012) konsep diri merupakan variabel yang akan ikut menentukan bagaimana individu merasakan, menerima, dan merespon diri dan lingkungannya. Apabila individu menilai dirinya kurang baik, maka individu akan menganggap remeh dan membayangkan kegagalan usahanya, sedangkan bila individu menerima dirinya baik, maka individu akan bersikap optimis terhadap usahanya sehingga kemungkinan untuk sukses tinggi.

Motivasi berprestasi merupakan daya penggerak yang memotivasi semangat bekerja seseorang, yang mendorong seseorang untuk mengembangkan kreativitas dan menggerakkan semua kemampuan serta energi yang dimilikinya demi mencapai prestasi kerja yang maksimal. Berdasarkan hasil wawancara awal dengan remaja awal panti asuhan, beberapa mereka mengatakan masih mengalami masalah pada fasilitas yang diberikan di panti, yaitu minimnya 


\section{K. D. L. PRABADEWI DAN P. N. WIDIASAVITRI}

donatur yang datang ke panti memberikan sumbangan sehingga para remaja mengaku cukup kesulitan dalam membeli peralatan belajar yang lengkap guna mendukung proses belajar mereka di sekolah. Peneliti berasumsi dengan terbatasnya sarana prasarana yang terdapat di panti, menjadi salah satu faktor yang dapat menghambat remaja untuk dapat mengembangkan diri dan megejar prestasi yang mereka inginkan.

Terdapatnya hubungan yang positif antara konsep diri akademik dengan motivasi berprestasi pada penelitian ini sejalan dengan teori yang dikemukakan oleh Fernald dan Fernald yang mengatakan bahwa dalam memunculkan motivasi seseorang untuk berprestasi dipengaruhi oleh banyak hal, salah satunya adalah peranan konsep diri. Melalui hasil koefisien determinasi (r2) diperoleh hasil bahwa peranan konsep diri akademik terhadap pembentukan motivasi berprestasi adalah sebesar 34,5\% yang berarti terdapat $65,5 \%$ variabel lain yang dapat berprengaruh dalam memunculkan motivasi berprestasi. Variabel-variabel lain tersebut dapat berupa pengaruh keluarga dan kebudayaan, pengaruh dari jenis kelamin, dan pengakuan akan prestasi (Fernald \& Fernald, 1999).

Penelitian ini melibatkan 120 orang sebagai subjek yang terdiri dari remaja laki-laki dan remaja perempuan. Berdasarkan hasil kategorisasi skor yang diperoleh subjek pada skala konsep diri akademik diketahui bahwa terdapat 21 orang $(17,5 \%)$ subjek dengan kategori konsep diri akademik sangat positif, 76 orang $(63,33 \%)$ subjek dengan kategori konsep diri akademik positif, 22 orang (18,33\%) subjek dengan kategori konsep diri akademik menengah, dan 1 orang $(0,83 \%)$ subjek dengan kategori konsep diri akademik negatif. Sedangkan pada kategori konsep diri akademik sangat negatif tidak terdapat subjek, atau $0 \%$. Hal ini menunjukkan bahwa mayoritas remaja awal yang tinggal di panti asuhan di Denpasar memiliki konsep diri akademik yang positif. Sedangkan untuk kategorisasi skor pada skala motivasi berprestasi diperoleh bahwa subjek yang termasuk dalam kategori sangat tinggi ada 17 orang (14,17\%), kategori tinggi ada 64 orang (53,33\%), kategori sedang ada $36(30 \%)$, kategori rendah ada 3 orang (2,5\%), sedangkan untuk kategori sangat rendah tidak terdapat subjek, atau $0 \%$. Hal ini menunjukkan bahwa mayoritas remaja awal yang tinggal di panti asuhan di Denpasar memiliki motivasi berprestasi yang tinggi yaitu sebesar 53,33\%.

Pada penelitian ini, hasil yang didapatkan pada wawancara awal adalah beberapa remaja awal memiliki pandangan yang negatif terhadap dirinya. Seperti misalnya mereka mengatakan bahwa mereka mendapat perlakuan yang berbeda dari teman sekolah, mereka juga menganggap diri mereka tidak dapat dibanggakan karena hampir tidak pernah mendapat peringkat di sekolah, dan permasalahan psikologis lainnya. Sedangkan berdasarkan perhitungan secara statistik dalam penelitian ini menunjukkan hasil yang dominan positif, hal tersebut dapat terjadi karena pada proses wawancara awal, peneliti melakukan wawancara dengan remaja awal panti asuhan di tempat peneliti melakukan uji coba penelitian (try out), dan dalam penelitian ini, try out yang digunakan adalah try out tidak terpakai, maka subjek yang digunakan adalah berbeda dengan yang peneliti gunakan dalam penelitian, maka dari itu perbedaan hasil dapat terjadi. Disamping itu, berdasarkan hasil pengkategorisasian hasil skor penelitian, didapat hasil bahwa sebanyak 22 orang remaja awal panti asuhan masih memiliki konsep diri akademik menengah dan 1 orang remaja awal panti asuhan memiliki konsep diri akademik yang negatif, maka dapat disimpulkan bahwa walaupun sebagian besar remaja awal panti asuhan memiliki konsep diri akademik yang positif, namun masih ada beberapa remaja yang memiliki konsep diri akademik menengah, bahkan negatif, begitu pula halnya dengan motivasi berprestasi, yaitu sebanyak 3 orang remaja awal panti asuhan masih memiliki motivasi berprestasi yang rendah, dan 30 orang remaja awal memiliki motivasi berprestasi sedang.

Terdapat penelitian serupa yaitu penelitian oleh Syafnimar (2011) yang mendapatkan hasil yang cukup berbeda dari proses wawancara awal dan hasil yang didapat, yaitu pada wawancara awal, didapat hasil beberapa remaja menarik diri dan malu-malu saat diwawancara, serta mengatakan malu dan minder terutama ketika di sekolah, suka menyendiri, tidak percaya diri, dan merasa takut gagal. Sedangkan pada hasil penelitian diperoleh bahwa lebih dari sebagian remaja panti asuhan memiliki konsep diri yang positif.

Berdasarkan hasil penelitian maka dapat disimpulkan bahwa terdapat hubungan yang positif dan signifikan antara konsep diri akademik dan motivasi berprestasi pada remaja awal yang tinggal di panti asuhan di Denpasar. Hal tersebut mengindikasikan bahwa semakin positif konsep diri akademik yang dimiliki oleh remaja awal panti asuhan, akan meningkatkan keinginan atau motivasi mereka untuk berprestasi. Maka dari itu peneliti memberikan beberapa saran-saran untuk remaja panti asuhan, yaitu diharapkan remaja awal panti asuhan untuk lebih aktif dalam membangun hubungan dengan lingkungan sekitar panti asuhan misalnya dengan mengikuti kegiatan karang taruna di daerah tempat tinggal mereka, atau dengan mengikuti berbagai perlombaan yang diadakan di sekolah mereka, maupun dengan mengikuti berbagai ekstrakurikuler yang terdapat disekolah, dengan harapan dapat menghilangkan stigma-stigma negatif terkait penghuni panti asuhan, serta menghindari kecenderungan adanya perlakuan yang berbeda dari masyarakat terhadap penghuni panti asuhan. Maka, diharapkan nantinya para penghuni panti asuhan khususnya pada usia remaja awal dapat merasa bahwa mereka adalah bagian dari masyarakat yang utuh, tanpa ada perbedaan status dalam masyarakat sehingga 
diharapkan remaja tersebut dapat membentuk konsep diri yang positif, khususnya konsep diri secara akademik, dan dapat mempengaruhi keinginan mereka untuk berprestasi dengan baik.

Saran untuk pengasuh, diharapkan para pengasuh di panti asuhan lebih memperhatikan lagi anak-anak panti asuhan yang diasuh agar para penghuni panti asuhan tidak merasa kekurangan kasih sayang dan menganggap diri terabaikan atau merasakan adanya perbedaan perlakuan antar penghuni. Serta pengasuh diharapkan lebih memperhatikan hal-hal kecil yang dapat mempengaruhi konsep diri, khususnya konsep diri akademik pada remaja panti asuhan, seperti memberikan pujian apabila remaja panti telah berhasil berprestasi dalam hal apapun, mengingat pola asuh sebagai salah satu faktor penting dalam pembentukan konsep diri remaja. Dengan memperhatikan hal-hal kecil seperti misalnya memberikan pujian ketika remaja panti berhasil menyelesaikan tugas sekolahnya dengan baik, tentunya akan membuat remaja tersebut merasa dihargai dan diharapkan dapat memperkuat perilaku yang ingin dimunculkan, dalam hal ini adalah keinginan atau motivasi mereka untuk berprestasi.

Saran selanjutnya yang dapat diberikan adalah untuk masyarakat, diharapkan masyarakat lebih peduli terhadap kondisi remaja awal yang tinggal di panti asuhan, karena pada dasarnya mereka sama seperti remaja-remaja lainnya yang juga membutuhkan dukungan baik secara moril maupun materil.

Saran bagi peneliti selanjutnya, hendaknya lebih cermat dalam menyusun alat ukur psikologi yang akan digunakan dalam penelitian, agar skala yang digunakan bebas dari kecenderungan subjek untuk menjawab pada kesesuaian pilihan secara sosial (social desirability). Disarankan juga bagi peneliti selanjutnya untuk melihat dan menggunakan variabelvariabel lain yang mampu mempengaruhi motivasi berprestasi pada remaja sebagai variabel bebas, misalnya pengaruh keluarga dan kebudayaan, pengaruh peran jenis kelamin, dan pengakuan akan prestasi, sesuai dengan teori yang dikemukakan oleh Fernald dan Fernald (1999), atau dengan berdasarkan teori lainnya yang berkaitan dengan motivasi berprestasi.

Analisis dalam penelitian ini menggunakan analisis korelasi product moment, peneliti berikutnya disarankan mampu menggunakan analisis lain, misalnya dengan menggunakan uji perbedaan, dengan contoh melihat perbedaan motivasi berprestasi remaja panti asuhan laki-laki dan perempuan yang ditinjau berdasarkan konsep diri, namun tentunya dengan tidak melupakan syarat terpenuhnya uji asumsi. Penggunaan metode penelitian lain seperti metode penelitian kualitatif juga sangat disarankan peneliti, hal ini menjadi pertimbangan untuk peneliti selanjutnya agar mendapatkan hasil penelitian yang lebih mendalam.

\section{DAFTAR PUSTAKA}

Agustiani, H. (2006). Psikologi perkembangan. Bandung: Refika Aditama

Anonim. (2012). Glosarium penyelenggaraan kesejahteraan sosial. Retrieved mei 14, 2013, from Kementrian Sosial Republik Indonesia: http://www.kemsos.go.id/modules.php?name=glosariumkesos

Assahhra, M. F. (2012). Konsep diri remaja yang tinggal di panti asuhan (Studi kasus). E-Journal Psikologi.

Azwar, S. (2012). Penyusunan skala psikologi. Yogyakarta: Pustaka Pelajar.

Byrne, B.M. (1996). Academic self-concept: Its structure, measurement and relation to academic achievement. Handbook of self-concept. New York; John Wiley \& Sons.

Dariyo, A. (2004). Psikologi perkembangan remaja. Bogor: Ghalia Indonesia.

Dewi, S. S. (2011). Perlindungan hak-hak anak pelaku kejahatan dalam proses peradilan pidana. Retrieved mei 17, 2013, from http://www.kumham-jogja.info/karya-ilmiah/37-karya-ilmiahlainnya/257-perlindungan-hak-hak-anak-pelaku-kejahatandalam-proses-peradilan-pidana

Djamarah, S. B. (2011). Psikologi belajar. Jakarta: Rineka Cipta.

Fernald, L.D., \& Fernald, P.S. (1999). Introduction to psychology (5th ed). India : A.I.T.B.S. Publishers \& Distributor (Regd).

Guilford, J. P. (1956). Fundamental statistics in psychology and education. New York: Mc Graw-Hill Book Co. Inc.

Gross, R. (2013). Psychology: The science of mind and behaviour. Edisi keenam. Jakarta: Pustaka Belajar.

Huitt, W. (2009). Self concept and self esteem, educational psychology interactive. Valdosta: Valdosta State University.

Hurlock, E. (1999). Psikologi perkembangan: Suatu pendekatan sepanjang rentang kehidupan. Jakarta: Erlangga.

Jahja, Y.(2011). Psikologi perkembangan. Jakarta: Kencana.

Kusumawardani. (2012). Motivasi berprestasi pada mahasiswa fakultas psikologi universitas katolik soegijapranata ditinjau dari konsep diri. Skripsi. Universitas Soegijapranata.

Monks, F., Knoer, A., \& Haditono, S. R. (2006). Psikologi perkembangan: Pengantar dalam berbagai bagiannya. Yogyakarta: Gajah Mada University Press.

Prabawa, Johan (2009). Faktor-faktor yang mempengaruhi perkembangan konsep diri remaja panti asuhan kristen tanah putih Semarang dilihat dari teori rogers. Skripsi. Universitas Katolik Soegijapranata Semarang.

Riduwan, \& Sunarto. (2009). Pengantar statistika untuk penelitian pendidikan sosial, komunikasi, ekonomi, dan bisnis. Bandung: ALFABETA.

Santrock, J. W. (2007). Remaja (Edisi kesebelas) Jakarta: Erlangga.

Sarwono, S.W. (2012). Psikologi remaja. Cetakan ke lima belas. Jakarta: Rajawali Pers.

Soepeno, J. (2011). Panti Asuhan dan Masalah Anak Jalanan. Retrieved mei 15, 2013, from Digidownload: http://digidownloadgratis.blogspot.com/2011/10/panti-asuhandan-masalah-anak-jalan.html

Sugiyono. (2008). Metode penelitian kuantitaf, kualitatif. Bandung : CV Alfabet.

Susilowati, K. (2011). Hubungan antara konformitas teman sebaya dan konsep diri dengan kemandirian pada remaja panti asuhan 


\section{K. D. L. PRABADEWI DAN P. N. WIDIASAVITRI}

muhammadiyah karanganyar. ringkasan skripsi. Universitas Sebelas Maret.

Syafnimar, D. (2011). Hubungan komponen konsep diri dengan prestasi belajar pada remaja awal (12-16 tahun) di panti asuhan aisyiyah cabang ampang tahun 2011. Ringkasan skripsi. Fakultas Keperawatan Universitas Andalas. 